\title{
Title:
}

\section{Tofacitinib, useful option for the treatment of pyoderma gangrenosum in an ulcerative colitis patient}

\section{Authors:}

Pablo Salmón Olavarría, Saioa Rubio Iturria, Óscar Nantes Castillejo

DOI: $10.17235 /$ reed.2021.7977/2021

Link: PubMed (Epub ahead of print)

Please cite this article as:

Salmón Olavarría Pablo, Rubio Iturria Saioa, Nantes Castillejo Óscar. Tofacitinib, useful option for the treatment of pyoderma gangrenosum in an ulcerative colitis patient. Rev Esp Enferm Dig 2021. doi:

10.17235/reed.2021.7977/2021.

This is a PDF file of an unedited manuscript that has been accepted for publication. As a service to our customers we are providing this early version of the manuscript. The manuscript will undergo copyediting, typesetting, and review of the resulting proof before it is published in its final form. Please note that during the production process errors may be discovered which could affect the content, and all legal disclaimers that apply to the journal pertain. 
CC 7977

Tofacitinib, a useful option for the treatment of pyoderma gangrenosum in an ulcerative colitis patient

Pablo Salmón Olavarría, Saioa Rubio Iturria, Óscar Nantes Castillejo

Department of Gastroenterology. Complejo Hospitalario de Navarra. Pamplona, Spain

Correspondence: Pablo Salmón Olavarría

e-mail: salmonpbl@gmail.com

Keywords: Tofacitinib. Pyoderma. Colitis.

Conflicts of interest: the authors declare no conflicts of interest.

Dear Editor,

Pyoderma gangrenosum (PG) is a difficult-to-manage ulcero-necrotizing dermatosis associated with inflammatory bowel disease (IBD) (1). In this article, we report a refractory $P G$ in a patient with severe ulcerative colitis (UC) that responded to tofacitinib $10 \mathrm{mg} / 12 \mathrm{~h}$.

The case was a 69-year-old female diagnosed in 2013, who was refractory to mesalazine, azathioprine, and infliximab. In 2019 she responded to cyclosporine and vedolizumab. In May 2020, she presented with arthralgias and three skin pustular ulcerative lesions. The larger one was located in her left knee and was $4 \times 5 \mathrm{~cm}$ in size. The other lesions measured $2 \times 2 \mathrm{~cm}$, and were located in her left ankle (Fig. 1) and perianal region. The suspected diagnosis of PG was histologically confirmed. Prednisone $1 \mathrm{mg} / \mathrm{kg}$ was prescribed, without clinical response. She also presented diarrhea and rectal bleeding with serum hemoglobin of $10.5 \mathrm{mg} / \mathrm{dL}, 2 \times 10^{9}$ leukocytes/L, PCR of $293 \mathrm{mg} / \mathrm{L}$, hypoalbuminemia, and fecal calprotectin at 6.377 
$\mathrm{mg} / \mathrm{kg}$. Tofacitinib $10 \mathrm{mg} / 12 \mathrm{~h}$ was started after a rectosigmoidoscopy that confirmed severe affectation and excluded cytomegalovirus infection. Digestive symptoms and arthralgias subsided in two weeks, and pyoderma lesions progressively improved and finally disappeared after a month (Fig. 1). She only developed arterial hypertension as an adverse effect. She gave her informed consent to publish this article.

There are three publications where tofacitinib was used to treat PG associated with Crohn's disease refractory to different therapies (golimumab and cyclosporine, ustekinumab, and vedolizumab). Complete remission of the lesions was achieved in twelve weeks in all cases (2). There is one reported case of PG associated with refractory UC that finally responded to tofacitinib and infliximab (3).

Tofacitinib has proven to be an effective treatment for refractory UC (4). Although its effectiveness for extraintestinal manifestations has not yet been evaluated, this clinical case is an indicator of its potential role in the treatment of PG associated with UC.

\section{REFERENCES}

1. Plumptre I, Knabel D, Tomecki K. Pyoderma gangrenosum: a review for the gastroenterologist. Inflamm Bowel Dis 2018;24:2510-7. DOI: 10.1093/ibd/izy174

2. Kochar B, Herfarth N, Mamie C, et al. Tofacitinib for the Treatment of Pyoderma Gangrenosum. Clin Gastroenterol Hepatol 2019;17(5):991-3. DOI: 10.1016/j.cgh.2018.10.047

3. Gregory MH, Ciorba MA, Deepak P, et al. Successful Treatment of Pyoderma Gangrenosum with Concomitant Tofacitinib and Infliximab. Inflamm Bowel Dis 2019;25(7):e87-8. DOI: 10.1093/ibd/izz015

4. Sandborn WJ, Su C, Sands BE, et al. Tofacitinib as Induction and Maintenance Therapy for Ulcerative Colitis. N Engl J Med 2017;376(18):1723-36. DOI: 10.1056/NEJMoa1606910 

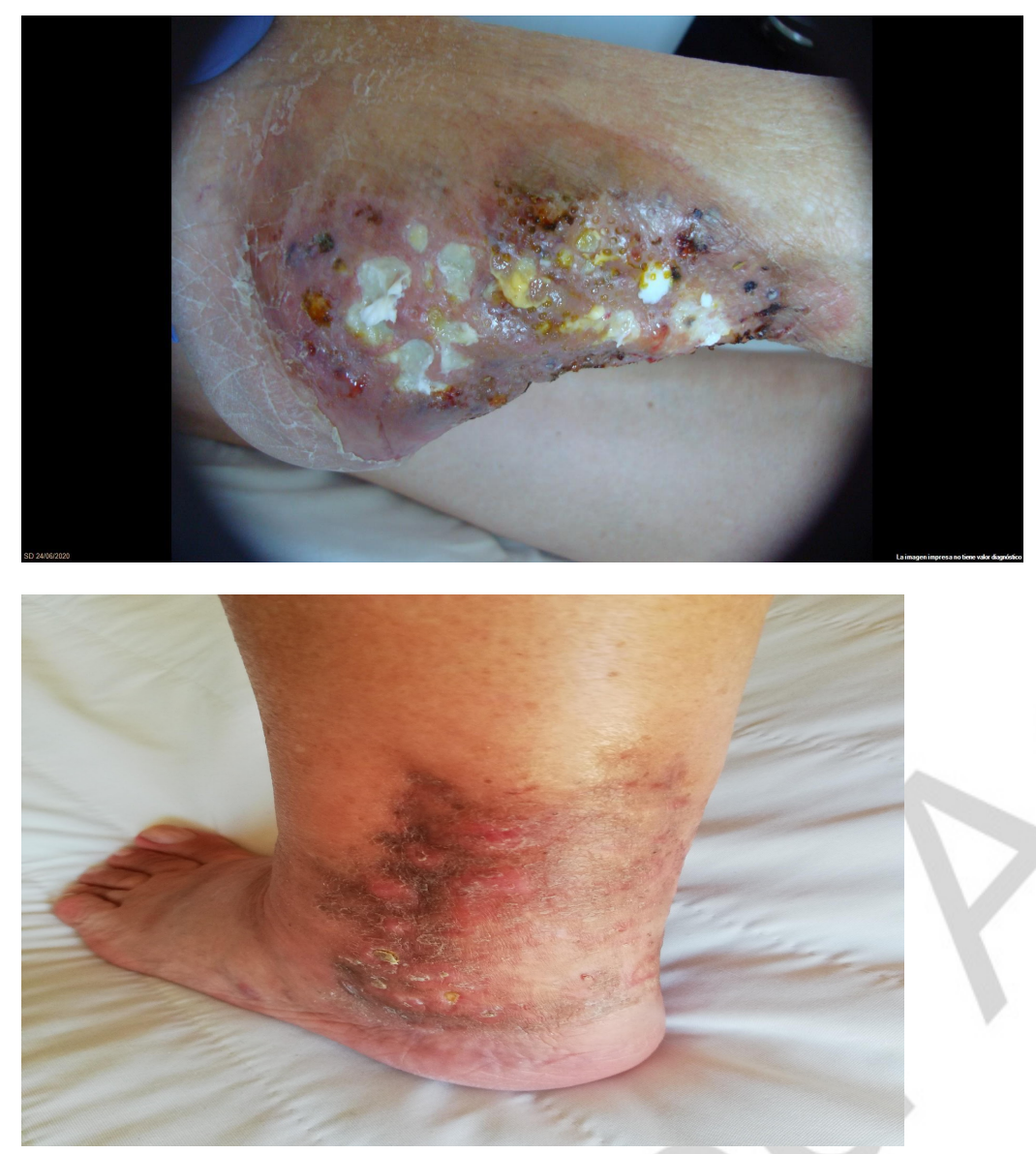

Fig. 1. Pyoderma lesion before and after treatment with tofacitinib. 